\title{
“As Mulheres de MisAel” - CORRUPÇÃO DE MENORES, ATENTAdOS AO PUdOR E ATOS LIBIDINOSOS NA COMARCA DE RIBEIRÃO PRETO, 1871 A 1942
}

\author{
Rafael De Tilio e Regina Helena Lima Caldana ${ }^{1}$ \\ Faculdade de Filosofia, Ciências e Letras de Ribeirão Preto - USP
}

O artigo tem por objetivo estudar processos criminais e inquéritos policiais de corrupção de menores, atentado ao pudor e atos libidinosos na comarca de Ribeirão Preto, ocorridos entre 1871 e 1942. Estes foram escolhidos por serem um recorte de outra pesquisa mais ampla sobre crimes sexuais no mesmo período (crimes sexuais e suas relações com a prática de casamento no Brasil), devido à sua importância no ordenamento social proposto pelo Código Penal de 1890. Estudadas suas aplicações na sociedade, refletidas na prática de produção de inquéritos policiais e processos criminais e suas intenções (para quem estavam destinados, quem eram seus autores, quais e os porquês de suas resoluções como casamentos, arquivamentos, perdões ou condenações), detectaram-se aspectos importantes. Dentre eles, o processo de construção de papéis sociais refletidos no casamento, de modo que a formação de famílias e sujeitos morais se adequasse à política difundida pela medicina-higienista e pela norma jurídica daquele período histórico, sendo punidos seus desviantes.

Descritores: Sexualidade. Crime. Família. Menor.

1 Respectivamente, Mestre em Psicologia pela FFCLRP/USP e Profa. Dra. dos cursos de graduação e pós-graduação em Psicologia na Faculdade de Filosofia Ciências e Letras de Ribeirão Preto/USP, Avenida Bandeirantes, 3900, campus da USP, Ribeirão Preto, SP, CEP 14040-901. Telefone: (16) 602-3804 / 602-3730. Endereço eletrônico: rafaeldetilio@pg.ffclrp.usp.br; rhlcalda@ffclrp.usp.br

Psicologia USP, 2005, 16(4), 147-174 
$\mathrm{D}$ e um século ao outro, do XIX para o XX e desse último para o nosso, vivemos um fenômeno social que não se dá sem repercussões (e dentre estas, inúmeras tentativas de resgate) que poderíamos denominar de "crise da memória”. Seria de fundamental importância que os pesquisadores das áreas de Humanidades se debruçassem, cada vez mais, como vêm fazendo nos últimos anos, sobre a possibilidade da promoção de um "resgate da memória”, de suas formas de produção e de seus produtos em formas de concepções, ideários e práticas sociais, para visualizarmos em que medida estas influenciam a contemporaneidade.

Apesar disso, pode-se (e certamente se deve) perguntar o porquê da importância da Psicologia se debruçar sobre o campo da História na realização de pesquisas de caráter histórico ou com documentos históricamente datados. A resposta mais adequada seria o reconhecimento de que todo e qualquer objeto de estudo da Psicologia possui uma inegável dimensão histórica em sua construção, com funções e significados, por muitas vezes, diferentes dos atuais, mas que influenciam esses últimos através de suas continuidades ou descontinuidades, que só seriam compreensíveis quando reconstruídas em seus registros e regimes contextuais específicos (Massimi, 1998). Ou seja, reconstruindo os “quadros mentais” de determinadas épocas, sem interpretálos a partir de valores hodiernos. E, também, de outra forma, por mais que descartemos e fujamos do passado, ele se faz constituinte de nossos comportamentos e idéias como indelével histórico não só pessoal (na forma da experiência anteriormente vivida), mas também social (aquilo que os antepassados construíram, e outros antes deles, e que nos influenciaria ainda hoje).

Dessa perspectiva, os fenômenos sociais assumiriam importante dimensão histórica, com valores e práticas que poderiam perpassar décadas, reformulando ou não seus significados, significados esses somente compreensíveis no plano do cotidiano (micro-história) ao qual pertenceram (Le Goff, 1986); e a compreensão desse cotidiano histórico, por sua vez, só se faria a partir dos sistemas históricos (macro-história), situando cada ator, por mais ínfimo, no funcionamento do sistema sociocultural ou simbólico do qual é ou foi integrante, possibilitando e permitindo, assim, o deciframento da realidade datada no passado. 
A Psicologia, ao se debruçar sobre a história das mentalidades, dos costumes ou mais recentemente da cultura, pode tentar aproximar o passado do presente, contribuindo para a construção de um saber sobre o homem, seus valores e concepções sem renegar (e tampouco obscurecer) sua importante fundamentação e desenrolar históricos, eximindo-se de interpretações de cunho etnocentrista ou anacrônica (Pesavento, 2003). Nessa tentativa de interdisciplinaridade, quem tende a ganhar é o conhecimento sobre os indivíduos e a sociedade, ao promover uma formulação de saber crítica e reflexiva (Dosse, 1992; Febvre, 1978).

Dessa maneira, o relato aqui apresentado faz parte de uma linha de pesquisa mais ampla, que parte da consideração da importância de se abrir um rasgo nas costas do tempo para ajudar a mostrar que certas práticas sociais, situadas em contextos específicos, visando à efetivação do matrimônio, poderiam estar relacionadas a determinadas situações de envolvimento na criminalidade sexual. Portanto, não se trata de considerar que essa criminalidade seja entendida com naturalidade ou como natural (isto é, de que todo crime visa ao aviltamento), mas sim, como fenômeno social, com diversas funções num contexto, pois, como nos revela o artigo 276 do Código Penal de 1890, havia, para determinados crimes (defloramento, estupro e rapto), a possibilidade da extinção da punibilidade do acusado quando a queixa resultasse no casamento com a vítima ${ }^{2}$.

O presente relato tece ponderações e considerações somente sobre um recorte da gama de crimes sexuais definidos pelo Código Penal de 1890, mais exatamente sobre os que não se adequavam ao artigo 276 e não permi-

2 Essa linha de pesquisa é coordenada pela Profa. Dra. Regina Helena Lima Caldana na FFCLRP-USP e estuda concepções, práticas e ideário sobre infância e família no Brasil. Resultou, entre outras, na Dissertação de Mestrado de Rafael De Tilio, intitulada Casamento e sexualidade em processos judiciais e inquéritos policiais na Comarca de Ribeirão Preto (1871 a 1942): concepções, práticas e valores, defendida, em 2005, na FFCLRP-USP, com apoio CAPES/CNPq. O objetivo principal desse trabalho foi obter informações relativas ao envolvimento na criminalidade sexual, defloramento, estupro e rapto, como maneira de tentar conseguir e efetivar, via auxílio da Justiça, o casamento diante de determinados impedimentos ou dificuldades (como proibições paternas, falta de dinheiro, gravidez precoce etc.). 
tiam a extinção da punibilidade do acusado por intermédio da contratação matrimonial (que eram os crimes de Corrupção de Menores, Atentados ao Pudor e Atos Libidinosos). Mesmo assim, inserem-se e só são inteligíveis num contexto histórico que estimulava e via na contratação matrimonial o relacionamento tido como ideal para homens e mulheres.

Esses crimes foram relatados em documentos judiciais nas formas de processo e inquéritos e são considerados de domínio público. Segundo alguns autores (Fausto, 2001; Hodder, 2000; Le Goff, 1988; Patlagean, 1990; Spink, 1999), são produtos datados, com componentes significativos do cotidiano de determinado período histórico e podem fornecer informações para entendermos comportamentos, atitudes, idéias e valores (bem como suas mudanças) dos envolvidos, por serem portadores de valores do imaginário social que modulariam os comportamentos dos indivíduos. Tal documentação serviria de material para refletirmos sobre o estabelecimento de padrões sociais normativos anteriores aos nossos, pelo simples fato de possuírem relatos transcritos de fala de envolvidos (acusados, acusadores, advogados, juizes e outros), restando serem contrapostos ao contexto social mais amplo para a elucidação dos papéis sociais, valores e táticas utilizadas , no que diria respeito às práticas de envolvimento na criminalidade sexual, visando ou não à efetivação do casamento (Souza, 1989).

E é consenso, entre esses autores, que tais documentos não se destinariam ao (r)estabelecimento da "verdade” do fato ocorrido (isto é, se as alegadas relações sexuais consentidas ou não, de fato, existiram), mas sim, à elucidação da construção dos atores judiciais envolvidos (acusados, queixosos, testemunhas etc.), de representações de masculino e feminino e de suas estratégias de confronto/obediência à norma.

Os processos criminais e inquéritos policiais de corrupção de menores, atentados ao pudor e atos libidinosos ${ }^{3}$, aqui relatados, estavam sob a guarda

3 Os documentos utilizados foram os seguintes: processo crime de Atentado ao Pudor, 12.1.1909, caixa 195, do $2^{\circ}$ Ofício de Processos Crime; processo crime de Atos Libidinosos, 13.12.1937, caixa 1, do $2^{\circ}$ Ofício de Processos Crime; processo crime de Corrupção de Menores, 2.2.1937, caixa 337, do $1^{\circ}$ Ofício A; processo crime de 
do extinto Arquivo do Fórum da Comarca de Ribeirão Preto (agora sob responsabilidade do Arquivo Público e Histórico de Ribeirão Preto) e compreendidos entre os anos de 1871 (o processo mais antigo localizado) e 1942 (quando passou a vigorar o Novo Código Penal Brasileiro, que reformulou a matéria dos crimes sexuais), arquivados em caixas do $1^{\circ}$ (coleções $A$, Processos Criminais e Diversos), $2^{\circ}$ (coleções Processos Criminais) e $4^{\circ}$ Ofício Cível (coleções Processos Criminais) ${ }^{4}$.

Mas para entendermos a especificidade e importância do estudo e utilização desse material, devemos primeiro entender breve e historicamente o contexto social que enfatizava a importância da contratação matrimonial e suas implicações, na legislação criminal brasileira de 1890.

Face ao exposto, em termos gerais, a maneira como se enxerga o casamento na República (como monogâmico) é fruto de construções históricas que remontam à filosofia grega do Estoicismo e à moral difundida há vinte séculos pelo Cristianismo. Em seus primórdios, o casamento oferecia para seus contratantes a saúde do corpo, o equilíbrio do espírito, o bem da comunidade, a promoção da fidelidade mútua e recíproca do casal, a prática da sexualidade visando, apenas, à procriação, em vez do uso desmedido do prazer, à manutenção da propriedade e do sistema de herança, à educação moralmente correta da descendência dentro da casa familiar, à perpetuação da idéia da família como espaço privilegiado do amor e da união, e da misogenia dos papéis sociais (Foucault 1999; Mott, 2001). Apesar das significativas mudanças ocorridas nos dois milênios que se seguiram, muitas dessas concepções permaneceram.

Corrupção de Menores (Pederastia), 6.9.1911, caixa 169 do $1^{\circ}$ Ofício A; inquérito policial de Atentado ao Pudor, 24.11.1941, caixa 6 do $4^{\circ}$ Ofício de Processos Crime.

4 Os processos e inquéritos do $1^{\circ}$ Ofício Cível-Proc.Crime, $2^{\circ}$ Ofício CívelProc.Crime e $4^{\circ}$ Ofício Cível-Processos Crime estavam catalogados em pastas próprias para consulta no Arquivo. O mesmo não ocorreu com o $1{ }^{\circ}$ Ofício Cível-A e $1^{\circ}$ Ofício Cível-Diversos, nos quais não havia forma alguma de classificação ou ordenamento e, nestes, os processos e inquéritos criminais sobre sexualidade foram manualmente separados dos cíveis. 
A virgindade pré-matrimonial e a continência do desejo sexual foram pilares e sustentáculos norteadores para a regulação da contratação matrimonial, cuja melhor representante seria a da figura da honradez e moralidade das mulheres (futuras mães e esposas), enfaticamente promovida e difundida pela Igreja Católica, desde o século III, na qual o recato e pureza (virgindade) seriam precondições para a efetivação dos casamentos. Monogâmico, heterossexual e indissolúvel, o modelo cristão do casamento competia com outras formas de união como os concubinatos, amasiamentos, divórcios e re-casamentos, então proibidos pela Igreja (Vainfas, 1986). O modelo cristão de casamento visava a garantir a manutenção dos bens e posses pelas classes abastadas e, sem menor importância, "moralizar” as uniões dos mais pobres que recorriam aos outros arranjos.

Nos séculos XII e XIII, a Igreja pôde confirmar sua preponderância (mas não a exclusividade) sobre as formas de união, por meio de estratégias como a confissão obrigatória, a sacralização do ritual do casamento e a perseguição dos concubinatários e hereges que não se curvassem aos seus ditames morais. Entretanto, mesmo com a difusão do casamento nas classes menos abastadas e a "necessidade" de cumprir com suas regras de contratação (que se destinavam ao controle da sexualidade por parte dos contratantes e dos futuros nubentes), como a manutenção da virgindade e honradez das mulheres antes da união e a contenção do desejo sexual na pós-união (ainda que, para os homens, as rigorosidades fossem mais amenas comparadas às das mulheres), existiram outras formas de satisfação sexual pré e pósmatrimonial, ou mesmo fora do casamento. É o caso das fugas e raptos combinados, estupros, “jogos pueris” (que só não permitiam a penetração vaginal, garantindo a vivência da sexualidade entre os amantes, sem que se ameaçasse o estatuto de sacralidade que representava a virgindade prénupcial), utilização de métodos contraceptivos e recorrência a prostituição que, se não permitidos, eram tolerados pela Igreja, a fim de promover certas válvulas de escape num sistema moral tão rígido (Flandrin 1987, 1988). Mesmo regrado, o rigor acerca da sexualidade poderia ser burlado.

Mais especificamente no Brasil, desde o Descobrimento, a sexualidade foi rigidamente controlada pela moral Cristã da Companhia de Jesus. Os 
nativos, que aqui há muito residiam, foram proibidos de andarem nus e de realizarem seus casamentos poligâmicos, os conventos foram proibidos de se estabelecer no Brasil e, também, foi proibido o envio de mulheres a conventos europeus; contudo, foi permitida a união entre brancos e índios e inúmeros foram os pedidos destinados ao rei para que enviasse mulheres brancas e casadoiras para que se instalasse a ordem familiar e o sistema de contratação de casamento em nossas terras, instigando as mulheres da Colônia a preservarem a virgindade pré-matrimonial (Vainfas, 1997).

No Brasil, bígamos, concubinatários, fornicadores e adúlteros foram severamente punidos pelos padres por não se adequarem aos ditames da família e do casal monogâmico. A criminalização da sexualidade desviante, tanto pela Igreja quanto pelas instituições públicas (representada, principalmente, pela classe médica e jurídica), permitiu que houvesse o estabelecimento de uma disciplina moralizante da sexualidade e a valorização do casamento e da austeridade familiar até o século XIX.

Na Colônia (passando pelo Império e também no início do século XIX), a repressão à sexualidade foi tamanha que às mulheres, em sua maioria, era permitido vivenciar sua sexualidade quase que exclusivamente no contexto pós-matrimonial. Elas foram adestradas e ensinadas ao trato doméstico e à submissão às figuras masculinas (primeiro ao pai, depois ao marido), preparadas para a preservação da virgindade pré-matrimonial e contenção dos desejos da carne após o casamento, visando principalmente à procriação e à educação dos filhos (Del Priore, 1997).

Em razão dos freqüentes casamentos arranjados pelos pais (Samara, 1988), restava às nubentes se consolarem com a esperança do surgimento de um sentimento de amor que as ajudasse a suportar as dificuldades da união (por vezes, indesejável), da vida a dois e da maternidade; esse sistema matrimonial priorizava a autoridade paterna e a valorização do patrimônio, havendo pouco espaço para os desejos e escolhas particulares e individuais de parceiros na contratação matrimonial (Lewkowicks, 1993).

O surgimento e a ênfase crescente no sentimento de amor tem marco apenas no século XVII na Europa, e no século XIX no Brasil. Esse senti- 
mento que, anteriormente, poderia mas, doravante, deveria existir entre os contratantes, teria como função primordial unir o casal e diminuir as diferenças de poder e alteridade entre homens e mulheres e entre os cônjuges (mas não eliminava o poder marital do esposo frente à esposa). Nesse contexto, o namoro ganhou importância, como espaço no qual a sexualidade pré-matrimonial poderia ser vivenciada com maior “facilidade.” Voltaremos a esse aspecto adiante.

O afrouxamento das relações patriarcais e da autoridade paterna no início da República - em conseqüência da urbanização, da industrialização e da diminuição do prestígio social ligado exclusivamente à terra - abriu espaço para que a preferência pessoal fosse cada vez mais freqüente na escolha dos parceiros, podendo ser feita pelos próprios interessados e não mais, unicamente, pelos pais (Lewkowicks, 1989; Nazzari, 1989).

Nesse período, o namoro e o amor pré-nupcial passaram a ter papel fundamental na escolha e na efetivação dos casamentos, pois o nubente poderia apresentar suas intenções à família do outro nubente e esse espaço poderia se constituir como locus privilegiado (mas não o único) da sedução física pré-nupcial. Ou então, por vezes, a apresentação de intenções entre os namorados por si só poderia dar ao namoro este sentido, podendo a perda da virgindade da mulher ser utilizada como mecanismo de confronto às normas e ao não-consentimento dos pais às suas escolhas, pois o exercício da sexualidade pré-matrimonial contestaria a autoridade paterna, “forçando” um casamento com o escolhido, após a revelação da perda da virgindade da mulher (peça importante nesse sistema), fazendo do casamento uma união baseada, principalmente, no amor entre os interessados (Trigo, 1989) ${ }^{5}$.

O que contestavam os namorados/nubentes não era a importância do casamento, da virgindade pré-matrimonial e da descendência como mecanismos de aceite e prestígio moral/social, mas sim, as formas pelas quais essa contratação era reconhecida e efetuada (pela submissão aos desejos e

5 Tuon (1997) comenta os raptos combinados e outros crimes sexuais em Ribeirão Preto, entre 1880 e 1920, noticiados por jornais, e Fonseca (1992) cita a existência de fugas combinadas para casar, ainda no Brasil da década de 1980. 
imposições paternas, cujo consentimento era inalienável para validar a união). Assim, as mulheres poderiam, doravante, utilizar o expediente da própria virgindade como "moeda de troca”, forçando o aceite de parceiros e/ou dos pais. Mas a mulher, mesmo diante dessas mudanças, permaneceu estancada na misogenia sexual repressiva que preconizava a honradez e a virgindade (no surgimento de teorias como a do instinto materno e da inferioridade biológica das mulheres) e, novamente, submissa à autoridade masculina e resguardada às funções de procriação (mãe) e de educação dos filhos.

Nesse ponto se insere a problemática da criminalidade sexual: se o exercício da sexualidade pré-nupcial era, por vezes, admissível, quando ligada à contratação de casamento (casos de raptos, estupros e defloramentos para conseguirem se casar com auxílio da Justiça, conforme estabelecia a legislação de 1890), por vezes, era punida quando se afastava das prerrogativas da contratação matrimonial. Nesse caso, aproximava-se do exercício "livre da sexualidade" (relações que não visavam à contratação e à reprodução), representada e demonstrada nos processos e inquéritos de corrupção de menores, atentados ao pudor e atos libidinosos.

Se no Brasil, da passagem do século XIX para o XX, o casamento foi incentivado maciçamente como maneira de se garantir o ordenamento social, as reformulações nos códigos legislativos, ocorridas naquele período, também foram reflexos de uma política social que pretendeu normatizar a sexualidade e as práticas correlatas de contratação matrimonial, incentivadas por médicos e juristas para a formação das chamadas famílias higiênicas e morais, punindo os que subvertessem as normas sociais e garantindo, assim, a estabilidade social (Esteve, 1989). O Estado, por meio do aparato jurídico organizado e difundido, tomou (ou partilhou) da Igreja a responsabilidade da definição e ordenamento das normas e impedimentos da contratação matrimonial (Lara, 1999).

As mudanças legislativas no período visaram, segundo Silva (1984), à moralização da população por intermédio da punição àqueles contrários à doutrina estatal de promoção e propagação de papéis sociais e casamento, difundindo para tanto, na República, um modelo que seria considerado o 
ideal para a sexualidade e família: sexo restrito ao casamento com mulheres recatadas, pudicas, virgens e castas, destinadas a serem zelosas do lar, do marido e dos filhos, e homens voltados para a esfera pública do trabalho, como forma de sustento do lar e da família. Qualquer afrontamento à figura feminina e sua sexualidade deveria ser coibido a fim de se preservar as montagens da família e do casamento como pedras angulares da sociedade (Rago, 1991; Vargas, 1999).

Os crimes cometidos contra a ordem familiar e, especialmente, os que atentassem contra a honra e sexualidade das mulheres, eram punidos com rigor (Delmanto, 1986; Gama, 1929). Mas para os defloramentos, raptos e estupros a legislação garantia a extinção da punibilidade (artigo 276, Código Penal 1890) àqueles acusados que se casassem com as vítimas (desde que 0 representante legal da mesma ou a própria, quando em situação em que já se representava, aprovasse), o que se revela como incentivo institucional à contratação matrimonial - como maneira reparatória de vitimizações sexuais ou como as já citadas estratégias de contestação da autoridade paterna.

Especificamente no Código Penal de 1890, os artigos que tratavam sobre crimes sexuais estavam intitulados "Dos crimes contra a segurança das famílias e do ultrage público ao pudor” (sic.) e eram divididos em cinco capítulos, sendo os mais interessantes para nosso propósito os dois primeiros. Devemos notar que a proteção a esses crimes estava destinada às famílias, e não aos direitos sexuais das vítimas.

O primeiro capítulo especificava os crimes sexuais contra a honra das mulheres (e dos homens) que seriam o Atentado ao pudor, a Corrupção de menores, os Atos libidinosos, o Defloramento (a perda da virgindade), o Rapto e o Estupro.

O primeiro dos artigos desse capítulo, de número 266, especificava os crimes que envolviam relações sexuais cometidas com atos diferentes da conjunção carnal (coito vaginal), que eram o Atentado ao pudor, Corrupção de menores e Atos libidinosos. O crime de Corrupção de Menores era definido pela prática de atos desonestos (anais, orais ou quaisquer outros, sem haver penetração vaginal) contra pessoa de um ou outro sexo por meio de 
violências ou ameaças contra as vítimas, com idade inferior a 16 anos, tendo por objetivo "viciar a sua innocencia ou pervertendo-lhe, de qualquer modo, o seu senso moral” (Gama, 1929, p. 292) e era punido com reclusão celular entre seis meses a dois anos; o crime de Atos Libidinosos era definido como práticas repetidas de atos desonestos e diferentes da conjunção carnal, contra menores de idade entre 16 e 21 anos, de um ou outro sexo, e era punido com reclusão celular de dois a quatro anos; o crime de Atentado ao Pudor era similar ao anterior (práticas desonestas contra vítimas de 16 a 21 anos, com reclusão de um a três anos), mas supunha a prática isolada dos atos sexuais. Esses crimes estavam destinados a promover a segurança de crianças e adolescentes como garantia de manutenção do status quo ${ }^{6}$

O artigo 267 definia o crime de Defloramento, que seria a perda de virgindade de mulheres menores de 21 anos, empregando sedução, engano ou fraude (promessas de casamento ou de dinheiro entre tantas outras formas). Nos comentários a esse artigo, há a seguinte afirmação de Gama (1929, p. 295): “a cópula do offensor com a offendida, sua noiva, faz presumir a sua responsabilidade pelo defloramento desta, pouco importando a declaração de já tel-a encontrado deflorada”, o que faz referência clara à importância do namoro como promessa implícita de casamento e intenção de futura contratação matrimonial. A pena para esse crime era de um a quatro anos de prisão celular.

O crime de Estupro era regulamentado por dois artigos (268 e 269), que o definiam como:

a) ato sexual cometido com abuso de violência (Gama, 1929, p. 296), e

por violência entende-se não só o emprego da força physica, como os meios de privarem a mulher de suas faculdades physicas, e assim da possibilidade de resistir e defender-se, como sejam o hypnotismo, o chlorofórmio, o eter, e, em geral, os anesthesicos e narcoticos.

6 Os extratos provenientes do material colhido dos documentos serão citados com a grafia original, sem correções gramaticais. 
Pouco importava se a mulher fosse virgem ou não, mas honesta - que seria um qualificativo moral da ofendida, refletido em seu comportamento e não reduzido à presença/ausência do hímen. Essa moralidade subjacente requerida às ofendidas era medida e estipulada por meio de seu comportamento, considerado aos olhos da sociedade, e refletiria no tempo de punição destinado aos condenados: caso a ofendida fosse honesta, punição de um a seis anos para o condenado (art. 268 parágrafo 1, pois a virgindade seria um agravante), mas se a mulher estuprada fosse prostituta a punição seria de seis meses a dois anos (art. 268 parágrafo 2);

b) presunção de violência: mesmo se a ofendida consentisse com a prática sexual, mas tivesse dezesseis anos ou menos, a violência era considerada presumida e o crime de estupro cometido. Vê-se que o interesse maior dos juristas era punir àqueles que atentassem contra as moças de família e as menores.

Para a qualificação desses crimes algumas exigências eram requeridas, como por exemplo: a realização do Exame de Corpo de Delito por peritos (para que se constatasse a veracidade da acusação); a atestação da menoridade e da idade dos ofendidos deveria ser feita pela apresentação de documentação válida (certidão eclesiástica ou certificado de registro de nascimento); apresentação de Atestado de Miserabilidade, expedido por oficial competente (para os ofendidos que pediam auxílio e dispensa dos custos e apoio da Promotoria Pública); e a apresentação de testemunhas idôneas que confirmassem o ocorrido. Gama (1929, p. 294) esclarece que "as declarações dos offendidos, desacompanhados de quaesquer indícios, não bastam para a pronuncia do réu", prerrogativa que denotaria tanto a desconfiança das autoridades em relação às acusações realizadas por mulheres, que eram comumente as vítimas desses crimes (que poderiam ser sem moral e desonestas por desejarem contratar a qualquer custo casamento...), quanto a necessidade de verificação da veracidade do ato criminoso para não cometer injustiças contra os acusados/homens.

O segundo capítulo inicia-se com os artigos 270 e 271 que definiam o crime de Rapto: retirada do lar de mulher honesta, maior ou menor, solteira 
ou viúva, por meio de sedução, emboscada ou violência, sem que houvesse, necessariamente, a prática sexual. A punição estipulada era de prisão celular de um a quatro anos; mas se a raptada fosse maior de 16 anos (pois, se menor, haveria presunção de violência e, conseqüentemente, o crime seria de Estupro) e menor de 21 e prestasse seu consentimento com a fuga, a punição seria de reclusão celular de um a três anos; se o rapto se seguisse de defloramento ou estupro, o raptor incorreria na pena correspondente a qualquer desses crimes que houvesse cometido, com o aumento da sexta parte.

O artigo 272 versa sobre a Presunção de violência (essencial para o crime de Estupro) cometido contra as mulheres menores de dezesseis anos, mas tal presunção poderia cessar se fosse provado - ainda que se tratasse de menores de dezesseis anos - que o ofensor não praticou violência contra a ofendida ou que esta não era honesta. O artigo 273 trata dos Agravantes para quaisquer desses crimes, cuja pena seria aumentada na sexta parte - " 1 .si o criminoso for ministro de qualquer confissão religiosa; 2.si for casado; 3.si for criado, domestico da offendida, ou de pessoa de sua família” (Gama, 1929, p. 299) - ou na quarta parte - “4.si for ascendente, irmão ou cunhado da pessoa offendida; 5.si for tutor, curador, encarregado de sua educação ou guarda, ou por qualquer outro título tiver autoridade sobre ella” (Gama, 1929, p. 299). Além da pena e da interdição, o ascendente perderia todos os direitos sobre a pessoa e bens da ofendida.

A queixa dos crimes sexuais tinha caráter particular e carecia de representabilidade, prescrevendo o direito de queixa após o sexto mês da data de cometimento do crime (artigo 275); isso quer dizer que a parte ofendida teria de dar queixa por si só (se maior) ou ser representada por um parente ou representante instituído legalmente que detivesse o pátriopoder e a autoridade sobre o menor. O Ministério Público não poderia dar queixa, podendo apenas fomentá-la e promover a denúncia (grosso modo, pedir o julgamento) nas ocasiões cabíveis.

O artigo 274 diz respeito ao procedimento de intervenção, reservado ao Ministério Público, nos crimes sexuais, após a queixa particular, cujas possibilidades seriam as seguintes (Gama, 1929, p. 300): 
1.se a offendida for miserável ou asylada, 2.se da violência carnal resultar morte, perigo de vida ou alteração grave da saúde da offendida, 3.se o crime for perpetrado com abuso de pátrio-poder, ou da autoridade do tutor, curador ou preceptor.

Atenhamo-nos, por um instante, no primeiro ponto. A palavra miserável não é, em Direito, sinônimo de pessoa indigente, mas sim de pessoa que não dispõe de meios necessários para levar a termo um processo criminal (como o pagamento de taxas e selos e a contratação de advogados que a possa representar); assim, o Ministério Público poderia intervir, nessas condições, promovendo o acesso à Justiça às classes e indivíduos menos abastados, garantindo a promoção da punição aos acusados de crimes sexuais e/ou auxiliando aqueles que desejassem casar, que utilizavam tais estratégias.

E toda regulação da sexualidade pré-nupcial desembocava no já citado artigo 276 (Gama, 1929, p. 303), que especificava que

nos casos de defloramento, como nos de estupro de mulher honesta, a sentença, que condemnar o criminoso, o obrigará a dotar a offendida. Paragrapho único: não haverá imposição de pena, si seguir-se o casamento a aprazimento do representante legal da offendida, ou do juiz de orphãos, nos casos em que lhe compete dar ou supprir o consentimento, ou o aprazimento da offendida, si for maior.

Esse artigo demonstra, com a possibilidade da não-imposição de pena nesses crimes, o incentivo à prática do casamento. Os demais crimes sexuais (Atentados ao pudor, Corrupção de menores e Atos libidinosos) não gozavam dessa possibilidade, mas seus protagonistas (acusados e ofendidas) também estavam perpassados por representações, valores, idéias e concepções de união e casamento, papéis sexuais e sociais de homens e mulheres, moral e honra construídos e partilhados socialmente que visavam à contratação matrimonial, vide a ênfase, referida na legislação, da proteção destinada às vítimas honestas.

A partir desse cenário, composto em termos socioculturais, e da legislação criminal da época, propomo-nos a tecer comentários sobre casos documentados, para desenvolver pontos de reflexão sobre a temática (pois nossas indagações são de ordem qualitativa). Mesmo quando os processos não versavam diretamente e não permitiam a contratação matrimonial como 
maneira de extinguir a ação penal, pois estão inseridos, ajudam a compor, participam e são compreensíveis apenas quando contrapostos a um contexto histórico, no qual as práticas jurídicas estimularam e incentivavam uma certa divisão de papéis e a realização de casamentos.

Assim, o primeiro exemplo apresentado é um processo criminal de Atentado ao pudor, datado de 1909. Neste, não fica especificado quem foi o autor da queixa e se trata de um caso de abuso sexual de um pai (48 anos, italiano) contra sua filha (esse é o único caso no conjunto de inquéritos e processos em que há incesto). No depoimento, a filha (8 anos, brasileira, órfã de mãe) disse que dividia a cama com o pai na hora de dormir, por ser sua casa muito pequena, mas que ele, há uma semana, vinha praticando atos violentos (relações sexuais) contra ela, fato que contou à noiva do pai, que assustada com a conduta do noivo, por também ela ter uma filha pequena - a levou numa parteira para fazer exames ginecológicos.

O exame policial de corpo de delito realizado pelos peritos verificou que não houvera defloramento da vítima, mas seus genitais e ânus estavam traumatizados, podendo ter sido ocasionados, segundo os peritos, por um membro viril em ereção. As três testemunhas inquiridas disseram que ouviram, por diversas vezes, sempre às noites, a menor dizer e gritar ao pai "que não fizese mais aquillo que doia” (fl. 10 verso), e que o acusado, costumeiramente, andava armado pela cidade. Uma das testemunhas, que foi a parteira consultada, confirmou que chegou a examinar a menor, antes da queixa, e afirmou ter encontrado sinais de violência sexual.

Inquirido, o pai confirmou que dividia a cama com a filha, mas negou que a tenha violentado sexualmente. O juiz responsável, por temer a segurança da menor, ordenou a prisão preventiva do acusado. Iniciada a fase da denúncia, as testemunhas relataram que apesar da acusação, o réu era um homem trabalhador e esforçado para que nada faltasse à filha - essa informação será importante no cálculo da pena. Ouvidas novamente as testemunhas, o juiz decretou a pronúncia do réu, que, levado a julgamento, foi condenado pelo crime (do artigo 266, 272 e 273 n.4) de Atentado ao pudor, cuja pena foi calculada com atenuante (bom comportamento pregresso do réu: 
apesar da violência cometida, era bom pai e sustentava a filha) em 2 anos, 9 meses e 22 dias de prisão celular. $\mathrm{O}$ advogado do réu tentou apelar da decisão do juiz, alegando não haver provas substanciais de que o pai fora o autor do crime contra a filha, mas a apelação não foi aceita.

Devemos atentar que, mesmo num período histórico em que as relações pais-filhos passavam por reformulações, como a ênfase no sentimento de infância e pregação, por médicos e religiosos, ao maior cuidado e respeito para com os infantes, em um caso de incesto - suposto o ato mais "vil" nesse sistema, por inverter a lógica da estrutura familiar e da descendência não foi requerida a punição em grau máximo para o acusado; ao contrário, houve atenuante no cálculo da pena, baseado no bom comportamento anterior do acusado por ser trabalhador e nada deixar faltar ao sustento da filha e por cumprir com as exigências para o cuidado com a descendência.

Mas o que estaria em jogo nesse caso de relação incestuosa seriam duas posições distintas para o acusado: a de trabalhador e a de pai. A de trabalhador, o acusado cumpre, mas não, a de pai. Como no caso, o pai não poderia se casar com a ofendida, sua filha, foi condenado, e as razões para tanto só podem estar inseridas e ser compreendidas num sistema de relações esperadas entre adultos e crianças, que enfatizava a proteção dos infantes pelos adultos; se, por um lado, o pai tinha condições de cuidar sozinho de sua filha órfã, por outro, após cometer incesto, não teria mais - pois, com o crime, ele perde a autoridade e a guarda da filha - possibilidades de educála, por não mais possuir os requisitos exigidos e observados aos pais no contato com os filhos: imposição da autoridade através da decência e respeito; além do mais, segundo as testemunhas, seria tênue e dúbio o limite entre coerção e segurança, considerando-se que exercida por um sujeito que anda armado... O acusado, por não mais responder a partir da expectativa social de proteção destinada à figura paterna, foi punido.

Outro exemplo, o segundo, é o único inquérito policial de Atentado ao pudor encontrado no Arquivo, estava datado de 1941 e diferia radicalmente do anterior; nele, a queixosa, mãe da ofendida de 16 anos, diz que a filha namorava (namoro que a queixosa desaprovava) há mais de um ano e, após 
comentários de uma vizinha, desconfia que o namorado teria desonrado sua filha. Convocada a prestar depoimento, a menor confirmou o namoro e disse que, após todo esse tempo, o namorado não a pedia em casamento, mas que, há alguns meses (sem especificar quanto tempo), o namorado "vem cometendo atos de libidinagem, e pondo-lhe nas coxas e mesmo forçando seus órgãos genitaes com o membro" (fl. 4). Ela mesma admite desejar se casar.

O namorado (18 anos) confirmou a versão da ofendida e expôs seu desejo de se casar com ela, pois "conhece-a e namora a muito tempo, nunca tendo ouvido dizer qualquer cousa em desabono da sua conduta moral, prontificando a casar-se com ela afim de reparar o mal que lhe fez" (fl. 5).

Por meio do exame de corpo de delito constatou-se que não houve o defloramento, mas, como cita o médico responsável pelo exame, por intermédio das palavras da ofendida, seria provável que tenha havido as ditas práticas libidinosas; diante do ocorrido os namorados se casaram (a certidão de casamento está anexada aos autos) e o inquérito cessa. Curiosamente, como estabelece o artigo 276, a extinção da punibilidade pela realização de casamento estava reservada para casos de defloramento e estupro, tal permissão foi “erroneamente” estendida a esse caso: o fato de serem namorados com desejo mútuo de casamento (para reparar o mal causado) pode ter influenciado na tomada de decisão do Ministério Público e do juiz em não processar o acusado, o que contrariava a norma positiva da lei, mas ia direto ao incentivo do casamento.

Contraposições interessantes podem ser feitas ao processo de Atos de Libidinagem, datado de 1937, a partir desse segundo exemplo encontrado, que ocorreu entre namorados. A queixa foi dada pela mãe de uma menor (de 16 anos) e foi motivada pelo fato de a filha não ter dormido em casa na noite anterior à da queixa. A mãe descobriu, com uma amiga da filha, que ela tinha passado a noite com o namorado; com medo de a filha ter sido deflorada, a mãe procurou a Justiça. A menor, em suas declarações na delegacia, disse que namorava há dois meses e há um mês, aproximadamente, sob promessas de casamento, o namorado praticou com ela atos de libidinagem, os quais descreve da seguinte forma: 
deitada, tirou as calças, tendo então o acusado lhe introduzido o membro na vagina; que como se sentisse dor, tirou o corpo, tendo notado então que o acusado ainda continuou um pouco em cima dela; que esta se levantou, notando que havia um líquido esbranquiçado, meio grosso, que lhe esparramou pelas coxas (fl. 7 verso).

Após isso, pernoitou com o namorado. O exame de corpo de delito realizado não indicou a efetivação do defloramento, mas levantou a hipótese de o hímen da ofendida ser complacente, o que permitiria a cópula sem ruptura. As testemunhas ouvidas confirmaram o namoro e o pedido de casamento e ressaltaram que a ofendida sempre foi "moça direita e trabalhadora" (fl. 8 e ss.). O acusado (18 anos), em seu depoimento, confirmou o namoro, o pedido de casamento e a relação sexual, dizendo que "introduziu seu membro na vagina da vítima, tirando-o, entretanto, para acabar nas coxas” (fl. 16 verso).

Réu confesso, disse ainda que desejava se casar por gostar da ofendida. Como não bastava sua vontade e nem permitia a legislação que, nesses casos, o casamento extinguisse a punibilidade, o acusado foi denunciado (depois de ouvidas, novamente, as testemunhas) e pronunciado pela Promotoria Pública.

O acusado, após essa decisão judicial, resolveu fugir para não ser processado e por achar-se injustiçado (já que queria se casar), mas foi preso pelas autoridades policiais e levado, finalmente, a julgamento. Seu advogado de defesa tentou demonstrar a improcedência legal da ação penal, alegando que não houvera crime: como a vítima não possuía certidão de nascimento, sua idade foi presumida pelos peritos em 17 ou 18 anos, no momento do crime, e, podendo a vítima ser maior na ocasião, não caberia ação pública a seu favor; além do mais, o defloramento, com a existência ou não de hímen complacente, não ficou provado. Diz ainda o advogado que " $a$ vítima espontaneamente, tirou as calças, como se já fora habituada ao coito, instigando o recorrente para manter relações sexuais” (fl. 42), não havendo, por parte do acusado, libidinagem alguma. Esse pedido de recurso do advogado não foi aceito pelo juiz (pois o réu confessou a prática do crime, e o crime de Atos Libidinosos destinava-se a vítimas entre 16 e 21 anos, e a idade suposta da vítima, nesse caso, em nada diferiria por estar compreendida nesse limiar), que realiza o julgamento e o condena - baseado no artigo 266, parágrafo 
2 - a um ano de prisão celular (a menoridade do réu foi considerada atenuante), além da obrigação de dotar a ofendida.

Em que difere o caso anterior desse, já que, em ambos, os acusados confirmaram as relações sexuais mantidas em segredo durante meses, as promessas de casamento realizadas e o desejo de se casar? Qual a razão para no último caso os namorados, legalmente, não poderem se unir pelo casamento? Isto é, por que em casos similares a conduta legislativa e a resolução dos casos poderiam ser diferentes?.

No primeiro (o processo de Atentado), havia namoro e desejo de casamento por parte dos namorados, mas desaprovado pelos pais da ofendida, pois o ato atenta não só a honra individual mas também para a familiar, e a reparação do mal equivaleria a uma "expurgação" do ato cometido, um retratamento à moral da ofendida: melhor desonrada e casada do que solteira; mas de qualquer maneira o objetivo dos namorados em se casar foi conseguido. Talvez o fato de o acusado, no segundo caso (processo de Atos), ter fugido (comportamento não esperado de homens que assumem as conseqüências de seus atos) após não ter seu casamento autorizado e ter sido denunciado, tenha influenciado na decisão do promotor de pedir sua condenação e não permitir, mesmo extra-legalmente, como no primeiro, o casamento e a liberdade do acusado.

E a mudança de estratégia da defesa, feita pelo advogado, no segundo caso, é de extrema relevância: se não conseguida a absolvição enfocando os aspectos legais (idade, miserabilidade etc.) tenta-se consegui-la por meio da desqualificação moral da ofendida, moça "habituada ao coito” (ou seja, já acostumada a tais práticas e pervertida moralmente), que não se encaixava no ideal social esperado da feminilidade, não sendo merecedora da proteção da Justiça.

Essa estratégia parece ter sido costumaz, pois fato similar ocorreu num processo de Corrupção de menores (1937), o quarto em nossa série, que envolve um casal de namorados. A declaração prestada pelo pai da ofendida consta que a filha foi engravidada pelo namorado, namoro esse que tinha quase um ano e era bem-vindo por haver proposta de casamento para, 
no máximo, os próximos dois anos. Após seis meses do pedido de casamento, a filha contou ao pai que estava grávida.

A ofendida (17 anos) relata em seu depoimento que tivera com o namorado (o único, até então) relações sexuais datadas de seis meses, sem que houvesse penetração (e nessas ocasiões, sentia que um líquido lhe escorria pelas pernas) e só não se casaram porque brigaram há cinco meses e terminaram o noivado, e já naquela época seus fluxos menstruais cessaram. $\mathrm{O}$ exame de corpo de delito estabelece que o hímen da ofendida é do tipo complacente, mas que ela está grávida de cinco meses (o que prova a virgindade da mesma), que bem poderia ter acontecido por não ter havido cópula carnal, mas coito vulvar "em que o esperma pode franquear a vagina e atingir o útero” (fl. 9 verso).

As testemunhas ouvidas confirmaram o namoro e as propostas de casamento, enfatizando o fato de a ofendida ser mulher direita que não possui conduta que possa desaboná-la ou desmerecê-la. O acusado (21 anos), quando presta seu depoimento, confirma que namorou a ofendida e que a pediu em casamento, mas terminaram ao brigarem quando lhe contaram que sua noiva se encontrava, às escondidas, com um homem casado, e que nunca teve atos de libidinagem com ela e não pretende se casar. Denunciado pelo Promotor Público, o advogado do acusado prepara sua defesa, baseado nos depoimentos de outras testemunhas arroladas para a formação de culpa (que dizem que, após o término do namoro com o acusado, viram a ofendida em companhia de outro homem; que ela namorava vários homens simultaneamente, inclusive casados; e tivera, antes do acusado, outros namorados) e na suposição dos médicos peritos, que realizaram o exame de corpo de delito, que alegaram que o coito teria sido vulvar e não houvera ameaças ou violência por parte do acusado (que seriam imprescindíveis para a qualificação do crime previsto no art. 266), que a ofendida se ofereceu ao acusado (que a recusou), que não teria bom comportamento desde a infância e era dada a namoricos - isto é, desqualificando-a moralmente. 
A Promotoria argumenta que acusado e ofendida, na data alegada do crime, namoravam e que o tempo de gravidez combina com o tempo que passaram juntos, e

ainda que se admita que para argumentar que seja verdade que a vítima foi algumas vezes vista aos abraços e beijos com os seus (outros) namorados, nem por isso fica isento o denunciado de responsabilidade (fl. 54).

O acusado foi pronunciado formalmente. Expedido o mandado de prisão, o juiz realizou o julgamento, no qual a ofendida (para surpresa de todos) confessou ter namorado outros homens enquanto estava com o acusado e não sabia, com certeza, quem foi o autor de sua gravidez, pois já estava deflorada quando começou a namorar o acusado. Mesmo com a confissão da ofendida, o advogado de defesa insiste na absolvição de seu cliente, alegando que qualquer outro poderia ser o autor da gravidez, pois

a gravidez não pode ser conseqüencia do suposto coito vulvar praticado pelo denunciado, no dizer da vítima, portanto não é possível que os espermatozóides subissem pela perna acima, numa via dolorosa para elles, nessa arrancada em terreno próprio para sua sobrevivência e fossem alcançar os grandes lábios, os pequenos, franquearam a abertura do hímem e dahi, em mais um trajecto, atingirem o útero. (fl. 78),

e que a ofendida teria péssimo comportamento, o que não provaria a culpa de seu cliente. Diante da confissão e de todo o exposto, o juiz condenou o acusado a seis meses de prisão, alegando que "se houve provas pela pronuncia, não há para a condenação; contudo corroborou com corrupção, pervertendo-lhe o senso moral” (fl. 82), pois o que julgava não era o defloramento (do qual o acusado era inocente, segundo a própria ofendida), nem da gravidez (incerta), mas sim da prática de atos desonestos e corrupção da menor. E, nesse caso, a condenação se baseou na prerrogativa de que o comportamento do namorado influenciou na derrocada da moral (e discernimento) da ofendida, na escolha e no exercício de suas ações.

Outro caso de corrupção de menores (quinto e último exemplo por nós relatado, também envolve a desqualificação moral, mas, dessa vez, do acu- 
sado como estratégia de acusação), talvez seja o mais interessante por estar classificado no art. 266, intitulado "Pederastia”, crime que, como forma autônoma, não estava estabelecido no Código Penal de 1890. Datado de 1911, esse crime teve três vítimas arroladas, mas apenas uma delas depôs. O depoimento dado pela vítima, um menino de 11 anos, relatado pelo escrivão no mesmo dia em que a vítima manteve relações sexuais com o acusado, quando foram pegos em flagrante, foi o seguinte:

o acusado começou a dar beijos no declarante, e, em seguida tirou o paletó do declarante, desceu os suspensórios, tirou as calças, deixando o declarante só de meia e botinas, e, em seguida deitou o declarante de bruços sobre a cama delle e com o membro viril em erecção enfiou no ânus do declarante, tendo lhe causado pouca dor. (fl. 5 verso)

A vítima ainda relata uma outra ocasião, na qual foram ele, o acusado (de raça negra) e outros dois meninos buscar lenha no mato, a convite do acusado, e um dos garotos contou aos demais que o acusado fez, em diversas ocasiões, "porcaria em sua bunda" (fl. 6). A vítima disse que conheceu o acusado por intermédio de um amigo que também se deitava com o acusado e, para lhe fazer as vontades, recebia em troca doces e dinheiro. A polícia, após denúncias de vizinhos, vigiou a casa do acusado e o surpreendeu em pleno ato delituoso. As testemunhas que depuseram (seis) disseram que se deitavam com o acusado e citaram o nome de inúmeras outras que faziam o mesmo, que nessas ocasiões não havia violência, mas dinheiro, doces e presentes; ainda disseram que os meninos que freqüentavam a casa do acusado, lá estavam por não terem onde morar, e o acusado dava-lhes sustento e proteção em troca de manterem relações sexuais.

Em seu depoimento, o acusado, na presença da imprensa local (é de se presumir que o caso teve repercussão social), revela que não se satisfazia, mas já tentara manter relações sexuais com mulheres ou prostitutas, mas que, por medo de contrair doenças, preferia meninos, confessando que praticou atos de libidinagem e pederastia contra estes, com os quais dormia. Disse que só em Ribeirão Preto "botou na bunda” (fl. 17) de uns dez meninos, pois 
nem sempre conseguia introduzi-lhes no ânus, e que quando isso ocorre, arruma nas coxas dos meninos, fal-os deitar de lado com as pernas juntas, entre as quaes colloca seu membro viril até satisfazer seus desejos libidinosos (fl. 17).

O acusado foi preso e denunciado formalmente; as testemunhas (as mesmas seis) confirmaram que sofreram violência sexual diversas vezes, sempre seduzidas com presentes e doces, e uma delas revela que, em brincadeiras e para se vingarem em discussões, as crianças chamavam umas as outras de "mulheres de Misael” (apelido do acusado), como forma de desqualificação da masculinidade, por fazer alusão a dormirem e manterem relações sexuais com o acusado.

Depois de denunciado e pronunciado, o acusado se defendeu, dizendo que apenas dava abrigo para as crianças. Mediante as acusações, a Promotoria pediu a pena máxima estabelecida, por considerar a prática de dois crimes: quatro anos, por atos libidinosos, mais dois anos, por corrupção de menores, com o acréscimo de um sexto do tempo de reclusão (mais um ano), por ter sido o crime premeditado e com deliberação criminosa. O julgamento foi realizado e a pena estabelecida, em grau máximo, foi de 7 anos de prisão celular, a maior dentre todos os processos criminais sexuais (incluindo estupros, defloramentos e raptos) encontrados no Arquivo: o fato de o acusado ser de raça negra, ser considerado desempregado e ter cometido crime sexual contra crianças certamente influenciou as autoridades.

Nesse contexto, se a legislação brasileira, pelo art. 276 do código Penal de 1890, garantia, em alguns casos, a extinção da condenação pelo casamento, noutros, o casamento não era possível, se bem que, por vezes, o rigor da lei era substituído pelo bom senso dos legisladores - vide o segundo exemplo por nós relatado.

Dessa maneira, a principal diferença entre a possibilidade do casamento ou sua proibição (com a punição do acusado) não se assentava no julgamento, que tomava como parâmetro os fatores legais dos autos (os artigos e suas aplicações pautadas no código), mas, principalmente, nas características dos envolvidos ligadas a fatores denominados "extra-legais": seus comportamentos e atitudes diante da norma social de referenciais de papéis mascu- 
linos (trabalhadores, sensatos, respeitosos etc.) e femininos (castas, puras, voltadas para o lar, marido e filhos). Se os envolvidos possuíssem e/ou exercessem os referenciais de conduta tidos como ideais, no período, haveria grandes chances de obter o casamento, caso contrário, a punição seria o caminho a ser trilhado.

Essa concepção parte da linha de raciocínio de autores como ArnaudDuc (1991), Pimentel et al. (1998), Ribeiro (1999) e Rocha (2001) que consideram que o julgamento em casos de crimes sexuais não era o da violência cometida, mas sim, o da moralidade dos ofendidos (das vítimas mulheres e crianças), podendo mascarar a própria violência cometida com a pretensa “proteção” à família e às mulheres.

Essa proposta fica evidente nos casos relatados em que a condenação ou absolvição dos acusados estava diretamente relacionada à qualificação moral dos envolvidos: punição, no caso da violência sexual incestuosa paifilha (processo de Atentado ao pudor), do namorado que foge de suas responsabilidades ou que auxilia na corrupção moral e honra da namorada (processo de Atos libidinosos e de Corrupção de menores) e do negro, pederasta, violador dos corpos das crianças (processo de Corrupção de menores), ou seja, casos em que os protagonistas não se adequavam aos papéis sociais esperados; e absolvição dos namorados que desejam se casar (inquérito de Atentado ao pudor), norma do período, mesmo quando a letra da lei não permitia.

Historicamente, constata-se que os interesses dos juristas em propagar o matrimônio e condenar a criminalidade sexual, desvinculada dos papéis sexuais tradicionais e da doutrina ao estímulo dos casamentos por meio da formação de famílias morais, coincide com a introdução no Brasil, por parte dos médicos e dos educadores, de concepções que visavam à proteção de mulheres e crianças. As leis, em nome dessa proteção, concederam aos juizes o poder de intervir na organização familiar, regulando a sociedade por meio das uniões matrimoniais e aumentando o controle social por intermédio da sustentação dos papéis sociais esperados. Aos que se distanciavam, os grilhões. Por isso, a impossibilidade de compreender o envolvimento na 


\section{As Mulheres de Misael}

criminalidade sexual no período, desvinculada de seus sustentáculos de relações de gênero e sexo, que apontam para a necessidade do casamento.

De Tilio, R., \& Caldana, R. H. L. (2005). “Misael's women” - Minor's corruption, Costumes outrage and Libidinous acts at Ribeirão Preto (Brazil) judicial district, 1871-1942. Psicologia USP, 16 (4), 147-174

Abstract: The article's objective is study criminal-lawsuits and policeinquiry (minor's corruption, costume's outrage and libidinous acts) at Ribeirão Preto (Brazil) judicial district between 1871-1942. Part of another bigger research about sexual criminality (about sexual crimes and their relationship with marriage's practice in Brazil) connected at social ordenament proposed by the Penal Code (1890). Studied their social applications, reflected in the practice and production of police-inquiry and criminal-lawsuits and their intentions (who's authors; who's destiny; which and why's resolutions like marriage, achievements, condemnations or absolutions etc), these crimes teach us about the construction of social papers and the marriage's roles for the formation of families and subjects adjusted at medical (hygienist) and juridical norms policy at that era, and who miss this one's way punished..

Index terms: Sexuality. Crime. Family. Minor.

De Tilio, R., \& Caldana, R. H. L. (2005). «Les femmes de Misael »Corruption de mineurs, Ataqques à la honté et Actions libidineuses dans le zone juridique de Ribeirão Preto (Brésil), 1871-1942. Psicologia USP, 16 (4), 147-174

Résumé : Cet article a pour but d'étudier des processus criminels et enquêtes de corruption de mineur, attaquez à la honte et actions libidineuses dans le District de Ribeirão Preto (Brésil), entre 1871 et 1942. Ceux-ci ont été choisis car ils sont une coupure d'une autre recherche plus large sur les infractions sexuelles dans la même période (crimes sexuelles et leurs rapports avec le mariage au Brésil) dû à l'importance dans l'ordenance social proposé par le Code Punissable de 1890. Étudié leurs applications 


\section{Rafael De Tilio e Regina Helena Lima Caldana}

dans la société, contemplée dans la production des enquêtes et processus criminel et leurs intentions (pour qui a été destiné; qui était leurs auteurs; qui et pourquoi les raisons pour leurs résolutions comme les mariages, archivements, les pardons ou les condamnations), ces infractions nous envoient au question de la construction de papiers sociaux et le mariage objectivant la formation de familles et sujets moraux adaptée à la politique diffusée par le médecine-hygiéniste et pour la norme juridique de cette période, et les deviants châtié.

Mots clés: Sexualité. Criminalité. Famille. Mineur.

\section{Referências}

Arnaud-Duc, N. (1991). As contradições do Direito. In G. Duby \& M. Perrot (Orgs.), História das mulheres no Ocidente (pp. 97-137). São Paulo: Ebradil.

Delmanto, C. (1986). Código Penal de 1940. São Paulo: Freitas Bastos.

De Tilio, R. (2005). Casamento e sexualidade em processos judiciais e inquéritos policiais na Comarca de Ribeirão Preto (1871 a 1942): concepção, práticas e valores. Dissertação de mestrado, Faculdade de Filosofia, Ciências e Letras de Ribeirão Preto, Universidade de São Paulo, Ribeirão Preto, SP.

Del Priore, M. (1997). O corpo feminino e o amor: um olhar (século XVIII, São Paulo). In M. D’Incao (Org.), Amor e família no Brasil (pp. 31-55). São Paulo: Contexto.

Dosse, F. (1992).Os historiadores do mental. In F. Dosse, A história em migalhas: dos Annales a Nova História (pp. 84-93). São Paulo: Editora da UNICAMP.

Esteves, M. de A. (1989). Meninas perdidas: os populares e o cotidiano do amor no Rio de Janeiro da Belle Époque. Rio de Janeiro: Paz e Terra.

Fausto, B. (2001). Crime e cotidiano: a criminalidade em São Paulo (1880-1924). São Paulo: EDUSP.

Febvre, L. (1978). História e psicologia. In C. Mota (Org.), Febvre (pp. 108-121). São Paulo: Ática.

Flandrin, J.-L. (1987). A vida sexual dos casados na sociedade antiga: da doutrina da Igreja à realidade dos comportamentos. In P. Àries \& A. Bejin (Orgs.), Sexualidades ocidentais: contribuições para a história e para a sociologia da sexualidade (pp. 135-152). São Paulo: Brasiliense.

Flandrin, J.-L. (1988). Repressão e mudança na vida sexual dos jovens. In J.-L. Flandrin, O sexo e o Ocidente: evoluções das atividades e dos comportamento. (pp. 319-339). São Paulo: Brasiliense. 


\section{As Mulheres de Misael}

Fonseca, C. (1992). Honra, humor e relações de gênero: um estudo de caso. In A. O. Costa \& C. Bruschini, Uma questão de gênero (pp. 310-333). Rio de Janeiro: Rosa dos Tempos.

Foucault, M. (1999). História da sexualidade (Vol. 3). Rio de Janeiro: Graal.

Gama, A. D. (1929). Código Penal Brasileiro - Decreto 847 de 11 de Outubro de 1890. São Paulo: Acadêmica, Saraiva.

Hodder, I. (2000). The interpretation of documents and material culture. In N. K. Denzin \& Y. S. Lincoln (Ed.), Handbook of qualitative research (pp. 703-715). Thousands Oaks, CA: Sage Publications.

Lara, S. H. (1999). Ordenações Filipinas - Livro V. São Paulo: Companhia das Letras.

Le Goff, J. (1986). História do cotidiano. In G. Duby, P. Ariès, E. L. La Durie, \& J. Le Goff (Orgs.), História e nova História (pp. 73-82). Lisboa: Editorial Teorema.

Le Goff, J. (1988). As mentalidades: uma história ambígua. In J. Le Goff \& P. Nora, História: novos objetos (pp. 68-83). Rio de Janeiro: Francisco Alves.

Lewkowickz, I. (1989). Heranças e relações familiares: os pretos foros nas Minas Gerais do século XVIII. Revista Brasileira de História, 9(17), 101-114.

Lewkowicks, I. (1993). As mulheres mineiras e o casamento: estratégias individuais e familiares nos séculos XVIII e XIX. In A. C. Ferreira (Org.), História (Vol. 12, pp. 13-28). Assis: Editora UNESP.

Massimi, M. (1998). A história das idéias psicológicas: uma viagem no tempo rumo aos novos mundos. In G. Romanelli \& Z. M. M. Biasoli-Alves (Orgs.), Diálogos metodológicos sobre práticas de pesquisa (pp. 11-30). Ribeirão Preto, SP: Legis Summa.

Mott, L. (2001). A revolução homossexual: o poder do mito. Revista USP: Política e Participação, (49), 40-59.

Nazzari, M. (1989). Dotes paulistas: composição e transformações (1600-1870). Revista Brasileira de História, 9(17), 87-100.

Patlagean, E. (1990). A história do imaginário. In J. Le Goff (Org.), A história nova (pp. 291-316). São Paulo: Martins Fontes.

Pesavento, S. J. (2003). História \& história cultural. Belo Horizonte, MG: Autêntica.

Rago, M. (1991). O complicado sexo dos doutores. In M. Rago, Os prazeres da noite: prostituição e código da sexualidade feminina em são Paulo (1890-1930) (pp. 141164). São Paulo: Paz e Terra.

Ribeiro, C. A da C. (1999). As práticas judiciais e o significado do processo de julgamento. Dados - Revista de Ciências Sociais, 42(4), 691-727. 


\section{Rafael De Tilio e Regina Helena Lima Caldana}

Rocha, L. M. L. N. (2001). Poder judiciário e violência doméstica contra a mulher: a defesa da família como função da Justiça. Serviço Social e Sociedade: temas sóciojurídicos, (67), 112-123.

Samara, E. M. (1988). Estratégias matrimoniais no Brasil do século XIX. Revista Brasileira de História, 8(15), 91-105.

Pimentel, S. et al. (1998). Estupro, direitos humanos, gênero e justiça. Revista USP, (37), 58-69.

Silva, M. B. N. (1984). Sistemas de casamento no Brasil Colonial. São Paulo: Edusp.

Souza, M. C. C. C. de. (1989). Crise familiar e contexto social: São Paulo 1890-1923. Tese de doutorado, Faculdade de Educação, Universidade de São Paulo, São Paulo.

Spink, P. (1999). Análise de documentos de domínio público. In M. J. Spink (Org.), Práticas discursivas e produção de sentidos no cotidiano: aproximações teóricas e metodológicas (pp. 123-151). Rio de Janeiro: Cortez.

Trigo, M. H. (1989). Amor e casamento no século XX. In M. D’Incao (Org.), Amor e família no Brasil (pp. 88-94). São Paulo: Contexto.

Tuon, L. I. (1997). O cotidiano cultural em Ribeirão Preto: 1880-1920. Dissertação de Mestrado, Faculdade de História, Universidade Estadual Paulista, Franca, SP.

Vainfas, R. (1986). Casamento, amor e desejo no Ocidente Cristão. São Paulo: Ática.

Vainfas, R. (1997). Trópico dos pecados: moral, sexualidade e Inquisição no Brasil. Rio de Janeiro: Nova Fronteira.

Vargas, J. D. (1999). Familiares ou desconhecidos? A relação entre protagonistas do estupro no fluxo do Sistema de Justiça Criminal. Revista Brasileira de História, 4(40), 63-82.

Recebido em: 13.09.2004

Revisto e encaminhado em: 11.11.2005

Aceito em: 21.11.2005 